\title{
Wide QRS tachycardia after recent pulmonary vein isolation
}

\author{
R. S. Prisecaru · V. Costache
}

Accepted: 27 January 2021 / Published online: 15 February 2021

(C) The Author(s) 2021

A 48-year-old male was admitted to our hospital for palpitations. The electrocardiogram obtained on admission is shown in Fig. 1. Echocardiography and other testing revealed no abnormalities. Eight weeks earlier, he had undergone pulmonary vein isolation for paroxysmal atrial fibrillation. At discharge, he was started on treatment with anticoagulant, beta blocker and a Class 1C antiarrhythmic drug, flecainide.

Class 1C antiarrhythmic drugs, such as flecainide and propafenone, depress cardiac excitability and decrease conduction throughout the cardiac tissue due to use-dependent sodium channel blockade [1]. Because of slowed conduction through the His-Purkinje system [2], which is more pronounced at faster heart rates, class $1 \mathrm{C}$ antiarrhythmic agents can cause a rate-related aberrant conduction of supraventricular tachycardia [3], including atrial flutter with 2:1 conduction, that can mimic ventricular tachycardia.

Distinction is paramount to treatment and prognosis. The patient underwent a second procedure with mitral isthmus radiofrequency ablation and has had no palpitations recurrence since.

Conflict of interest R.S. Prisecaru and V. Costache declare that they have no competing interests.

Open Access This article is licensed under a Creative Commons Attribution 4.0 International License, which permits use, sharing, adaptation, distribution and reproduction in any medium or format, as long as you give appropriate credit to the original author(s) and the source, provide a link to the Creative Commons licence, and indicate if changes were made. The images or other third party material in this article are included in the article's Creative Commons licence, unless indicated otherwise in a credit line to the material. If material is not included in the article's Creative Commons licence and your intended use is not permitted by statutory regulation or exceeds the permitted use, you will need to obtain permission directly from the copyright holder. To view a copy of this licence, visit http://creativecommons.org/licenses/by/4.0/.

\section{References}

1. Ranger S, Talajic M, Lemery R, et al. Kinetics of use-dependent ventricular conduction slowing by antiarrhythmic drugs in humans. Circulation. 1991;83:1987-94.

2. Goldberger ZD, Rho RW, Page RL. Approach to the diagnosis and initial management of the stable adult patient with a wide complex tachycardia. Am J Cardiol. 2008;101:1456-66.

3. Alzand BS, Crijns HJ. Diagnostic criteria of broad QRS complex tachycardia: decades of evolution. Europace. 2011;13:465-72.

\author{
R. S. Prisecaru ( $₫)$ \\ European Hospital Polisano, Medlife Sibiu, Sibiu, Romania \\ raluvsirbu@gmail.com
}

R. S. Prisecaru $\cdot$ V. Costache

Lucian Blaga University, Sibiu, Romania 


\section{Heart Beat}

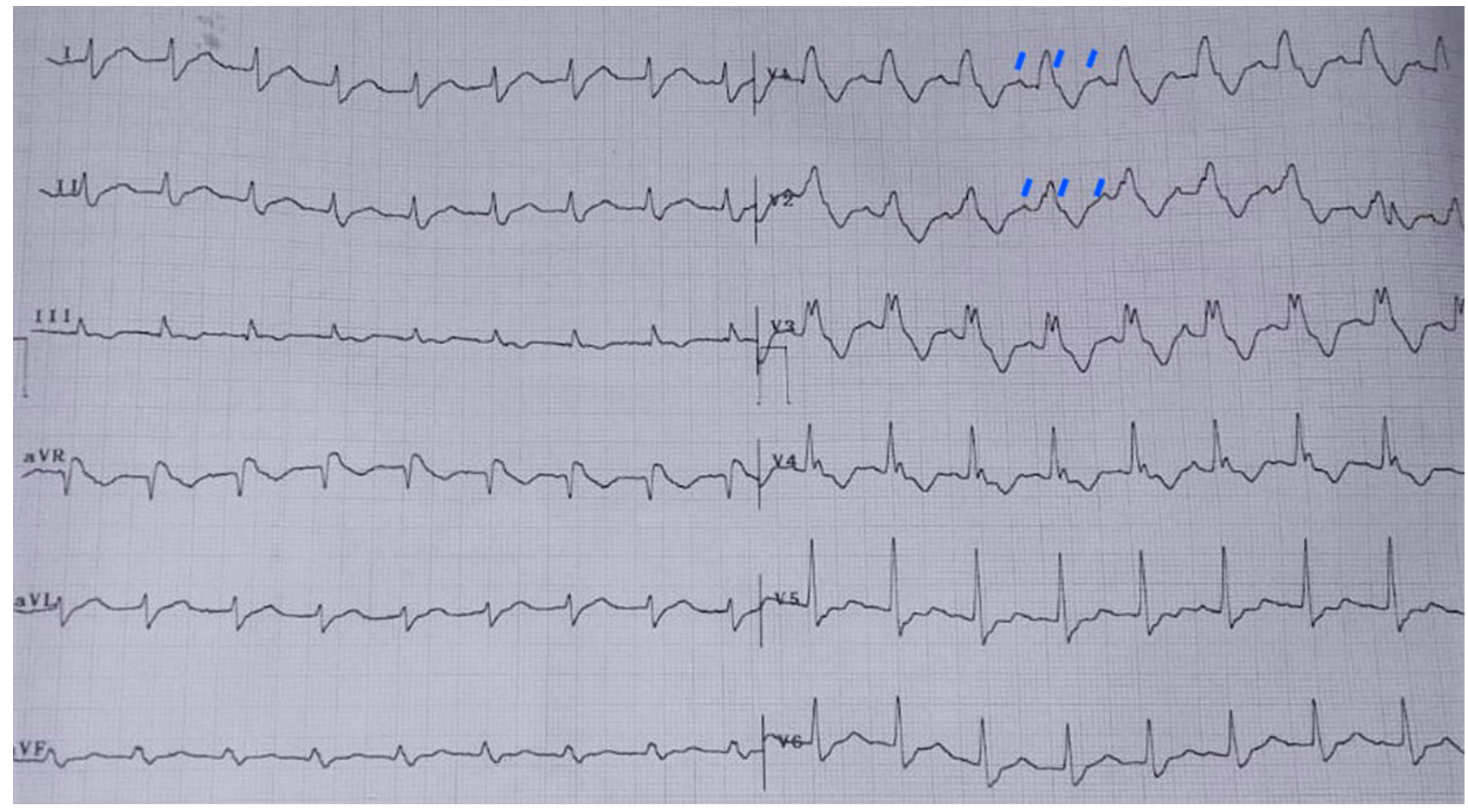

Fig. 1 Electrocardiogram shows a wide QRS tachycardia with right bundle branch block morphology. P waves are visible in precordial leads with 2:1 conduction, compatible with atrial tachycardia and aberrant conduction 